\title{
INOVASI TELUR ASIN ASAP PEDAS SEBAGAI PRODUK DIVERSIFIKASI PANGAN UNGGULAN DESA SUKANAGALIH KABUPATEN TASIKMALAYA
}

\section{INNOVATION OF SPICY SMOKE SALTED EGGS AS A LEADING FOOD DIVERSIFICATION PRODUCT IN SUKANAGALIH VILLAGE, TASIKMALAYA REGENCY}

\author{
Andri Kusmayadi $^{1{ }^{*}}$, Ristina Siti Sundari ${ }^{2)}$, Yusuf Sumaryana ${ }^{3)}$ \\ ${ }^{1)}$ Jurusan Peternakan, Fakultas Pertanian, Universitas Perjuangan Tasikmalaya \\ email: andrikusmayadi@unper.ac.id \\ ${ }^{2)}$ Jurusan Agribisnis, Fakultas Pertanian, Universitas Perjuangan Tasikmalaya \\ email: ristinasitisundari@unper.ac.id \\ ${ }^{3)}$ Jurusan Teknik Informatika, Fakultas Teknik, Universitas Perjuangan Tasikmalaya \\ email: yusufsumaryana@unper.ac.id
}

\begin{abstract}
ABSTRAK
Telur merupakan salah satu produk pangan asal hewan yang memiliki nilai gizi tinggi dan berharga murah sehingga banyak dikonsumsi oleh masyarakat. Telur asin merupakan produk olahan telur yang biasa dibuat dari telur itik dengan tujuan untuk meningkatkan masa simpan telur segar dan nafsu makan konsumen. Varian rasa telur asin saat ini cukup banyak, salah satunya yaitu telur asin asap. Telur asin asap rasa pedas merupakan inovasi diversifikasi pangan yang diharapkan dapat disukai konsumen dari berbagai golongan. Berbagai kegiatan pengolahan telur asin asap rasa pedas telah dilakukan di Desa Sukanagalih, Kecamatan Rajapolah, Kabupaten Tasikmalaya. Tujuan program pengabdian kepada masyarakat ini yaitu untuk meningkatkan keterampilan masyarakat dalam mengolah telur asin asap rasa pedas sebagai salah satu produk unggulan di wilayah tersebut. Metode pengabdian kepada masyarakat dilakukan dengan cara penyuluhan, pelatihan dan pendampingan pada kelompok mitra. Penyuluhan dilakukan dengan cara sosialisasi pentingnya diversifikasi pada produk pangan hewani. Pelatihan dilakukan dengan cara praktek pembuatan telur asin asap rasa pedas mulai dari telur itik segar sampai terbentuknya produk telur asin asap rasa pedas. Pendampingan dilakukan secara berkala pada kedua kelompok mitra agar semakin terampil dalam mengolah produk sampai pemasaran produk melalui berbagai media social dan ecommerce. Hasil kegiatan ini berupa meningkatnya keterampilan masyarakat dalam mengolah telur asin asap rasa pedas sehingga dapat dijadikan sebagai salah satu peluang bisnis masyarakat. Dengan meningkatnya keterampilan tersebut, pendapatan masyarakat meningkat pula karena adanya margin harga jual telur yang cukup tinggi antara telur itik segar dengan produk telur asin asap rasa pedas.
\end{abstract}

Kata kunci: Digital Marketing, Diversifikasi Pangan, Pengabdian Masyarakat, Telur Asin Asap

\section{ABSTRACT}

Eggs are one of the food products of animal origin that have high nutritional value and are cheap so that they are widely consumed by the public. Salted eggs are processed egg products which are usually made from duck eggs with the aim of increasing the shelf life of fresh eggs and consumer appetite. There are quite a lot of salted egg flavors, one of which is smoked salted egg. Spicy smoked salted egg is a food diversification innovation that is expected to be liked by consumers from various groups. Various activities of processing spicy smoked salted eggs have been carried out in Sukanagalih Village, Rajapolah District, Tasikmalaya Regency. The aim of this community service program is to improve community skills in processing spicy smoked salted eggs as one of the leading products in the region. The method of community service is carried out by means of counseling, training and mentoring to partner groups. Extension is carried out by socializing the importance of diversification in animal food products. The training was conducted by practicing making spicy smoked salted eggs, starting from fresh duck eggs to the formation of spicy smoked salted eggs. Assistance is carried out 
periodically for the two groups of partners to make them more skilled in processing products to marketing products through various social media and e-commerce. The results of this activity are in the form of increased community skills in processing spicy smoked salted eggs so that they can be used as one of the community's business opportunities. With the improvement in these skills, people's income has also increased due to the fairly high margin of egg selling price between fresh duck eggs and spicy smoked salted egg products.

Keywords: Digital Marketing, Food Diversification, Community Service, Smoked Salted Egg

PENDAHULUAN

Telur merupakan salah satu sumber protein hewani yang paling banyak dikonsumsi oleh masyarakat disamping daging dan susu karena bernilai gizi tinggi dan berharga murah. Telur itik memiliki kandungan gizi yang lebih tinggi dibandingkan dengan telur ayam maupun puyuh. Ketersediaan telur itik di Desa Sukanagalih cukup melimpah yaitu dapat mencapai 1.000 butir telur setiap harinya. Daya tahan telur segar yang mudah rusak maka diperlukan penerapan teknologi pengolahan telur. Pengawetan telur yang paling mudah dilakukan adalah dengan cara pengasinan menjadi telur asin [1]. Tujuan pengasinan pada telur selain untuk mengawetkan telur yaitu untuk mengurangi bau amis dan menciptakan rasa khas sehingga lebih disukai konsumen [2]. Metode pengasinan telur dapat dilakukan dengan metode basah yaitu dengan cara merendam telur itik pada larutan garam jenuh atau metode kering dengan cara membalut/membungkus telur menggunakan adonan garam dengan abu [1]. Metode basah memiliki kelebihan yaitu kemampuan penetrasi garam ke dalam telur dapat lebih cepat dibandingkan metode kering meskipun albumin telur relatif akan lebih basah [2].
Selain pengawetan dengan cara pengasinan, pengawetan telur juga dapat dilakukan dengan cara pengasapan. Pengolahan telur dengan cara pengasapan dapat meningkatkan daya tahan telur sampai 1 bulan dibandingkan telur asin rebus yang hanya bertahan selama 1 minggu [3]; [4]. Proses pengasapan dapat memperpanjang masa simpan telur [5] karena adanya asap dapat menutupi pori-pori pada kerabang telur [6] sehingga menghambat mikroba masuk ke dalam telur [3]. Hasil pengasapan pada telur menghasilkan warna yang lebih menarik yaitu coklat kehitaman, bau amis pada telur asin menjadi hilang dan menghasilkan aroma yang khas [3]. Di pasaran, harga jual telur asin asap jauh lebih tinggi yaitu dapat mencapai Rp 5.000 dibandingkan telur asin biasa yaitu sebesar Rp 2.500 - Rp 3.000.

Penambahan citarasa pedas pada produk telur asin asap dapat dikembangkan sebagai salah satu produk inovasi agar semakin disukai konsumen. Reringga dkk [7] melaporkan bahwa cita rasa pedas pada produk pangan dapat meningkatkan nafsu dan selera makan konsumen. Sumber daya manusia di Desa Sukanagalih cukup terampil dalam mengolah berbagai produk pangan maupun sandang. Di daerah ini banyak pengrajin berbagai kerajinan tangan maupun 
aneka makanan yang cukup variatif.

Kegiatan pengabdian masyarakat berbasis pengolahan telur asin asap rasa pedas di Desa Sukanagalih bertujuan untuk meningkatkan keterampilan masyarakat dalam mengolah telur asin asap rasa pedas sebagai salah satu alternative produk unggulan daerah ini.

\section{METODE PELAKSANAAN KEGIATAN}

Bahan dan peralatan yang digunakan dalam pengabdian ini yaitu telur itik segar, garam, air, cabai merah, bawang putih, toples tertutup, rak pengasapan, rak telur, kemasan telur yang berisi 6 butir dan 10 butir, label telur serta label kemasan.

Kegiatan pengabdian kepada masyarakat dilaksanakan pada bulan Maret sampai dengan September 2021 yang berlokasi di Dusun Cihateup, Desa Sukanagalih, Kecamatan Rajapolah, Kabupaten Tasikmalaya. Masyarakat yang menjadi peserta kegiatan ini yaitu anggota kelompok ternak "Kelompok Megar Bebek Cihateup", anggota "Badan Usaha Milik Desa (BUMDes) Berdikari Desa Sukanagalih" serta wanita tani di lingkungan Desa Sukanagalih. Peserta kegiatan pada setiap sesi terdiri atas 15 - 30 orang yang terdiri atas berbagai golongan usia, jenis kelamin serta latar belakang pendidikan.

Metode yang digunakan dalam kegiatan ini yaitu terdiri atas sosialisasi/penyuluhan tentang urgensi pentingnya dan strategi menjadi wirausahawan di bidang pertanian, pelatihan berupa praktek langsung mengolah telur itik segar menjadi telur asin asap rasa pedas, serta pendampingan secara dengan pengemasan produk.

\section{HASIL DAN PEMBAHASAN}

Kegiatan diawali dengan sosialisasi/penyuluhan tentang urgensi pentingnya dan strategi menjadi wirausahawan di bidang pengolahan pangan.

Sosialisasi ini ditujukan untuk meningkatkan pemahaman dan kesadaran masyarakat bahwa bisnis di bidang kuliner ini cukup menjanjikan dengan perputaran uang yang cepat serta dibutuhkan dalam kehidupan sehari-hari. Beberapa peserta kegiatan ini merupakan pengolah makanan juga sehingga sudah cukup terampil di dalam menyiapkan resep pengolahan makanan. Setelah itu dilanjutkan dengan praktek pengolahan telur asin asap rasa pedas.

Telur itik didapatkan dari para peternak itik yang ada di Desa Sukanagalih atau di sekretariat "Kelompok Megar Bebek Cihateup". Telur yang digunakan untuk pembuatan telur asin dipastikan yang masih segar dan berkualitas baik. Untuk menguji kualitas telur yang akan digunakan dapat diamati bagian dalam telur menggunakan alat candling yaitu berupa alat teropong telur. Selain itu, dapat diuji dengan cara telur dimasukan ke dalam wadah berisi air, ketika telur tersebut tenggelam maka dipastikan telur masih segar dan berkualitas baik. Berbeda dengan telur yang mengambang atau mengapung maka dipastikan kualitas telur sudah jelek dan tidak segar. Setelah telur dipastikan layak digunakan, selanjutnya telur tersebut dibersihkan dari kotoran yang 
menempel dengan dicuci menggunakan air bersih dan lap basah. Setelah dibersihkan, telur selanjutnya disimpan pada toples yang akan dijadikan sebagai wadah penyimpanan telur selama proses pengasinan berlangsung. Selanjutnya, larutkan garam di dalam air mendidih agar dipastikan larut dan bebas dari kontaminasi mikroba. Larutan garam selanjutnya didiamkan beberapa saat sampai dingin. Setelah dingin, larutan garam disiramkan di dalam toples yang sudah berisi telur tadi dan dipastikan semua telur terendam sempurna. Setelah terendam, masukan potongan cabai merah dan bawang putih ke dalamnya sampai tertutup sempurna. Selanjutnya, tutup toples tersebut dan biarkan selama $2-3$ minggu sampai telur tersebut dipastikan asin sempurna. Kegiatan pemilihan bahan baku telur dan penyimpanan pada media pengasinan disajikan pada Gambar 1.

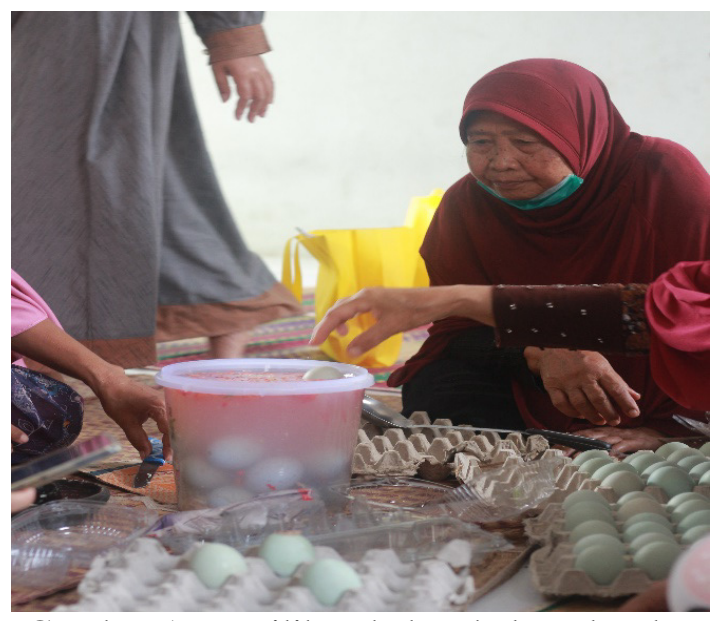

Gambar 1. Pemilihan bahan baku telur dan penyimpanan pada media pengasinan

Setelah proses pengasinan selesai, selanjutnya telur tersebut dikukus selama kurang lebih 2 jam di dalam panci kukus. Selanjutnya telur diasapi di dalam rak pengasapan sampai warna kerabang telur berubah menjadi coklat kehitaman selama 2 jam. Telur asin asap pedas tersebut selanjutnya dilakukan penempelan dengan menggunakan label dan dilakukan pengemasan menggunakan plastik kemasan telur yang berisi 6 dan 10 butir. Selanjutnya kemasan tersebut diberikan label seperti yang tersaji pada Gambar 2.

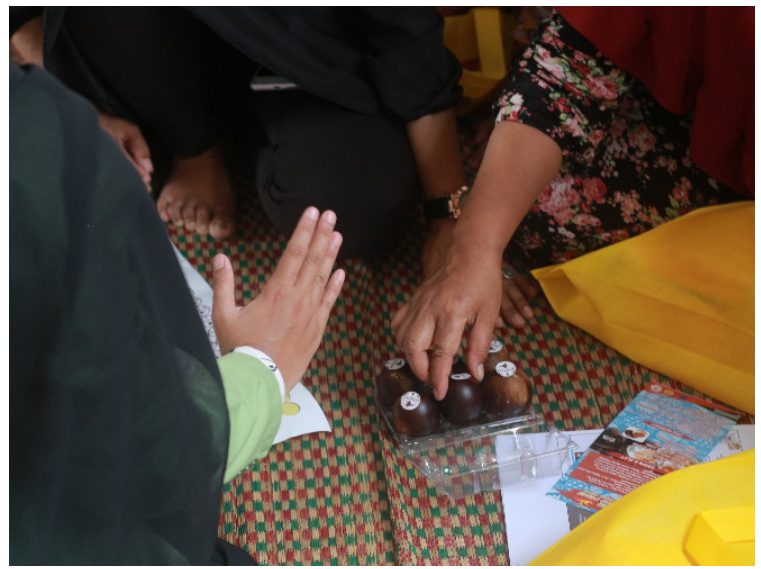

Gambar 2. Pengemasan dan labelisasi produk telur asin asap pedas

Setelah pelatihan pengolahan telur asin asap selanjutnya dilakukan sosialisasi kembali mengenai strategi pemasaran produk. Pemasaran produk dapat dilakukan secara offline maupun online. Desa Sukanagalih memiliki Badan Usaha Milik Desa (BUMDes) Berdikari yang cukup berkembang di dalam memasarkan produkproduk dengan adanya toko yang cukup besar. Sebagian besar produk yang dipasarkan pada toko BUMDes ini yaitu berupa kerajinan tangan. Produk hasil kegiatan ini dapat dijadikan sebagai salah satu alternatif produk unggulan makanan khas. Desa Sukanagalih merupakan lokasi domestikasi itik Cihateup sehingga kekhasan dari daerah ini perlu ditonjolkan. Selain 
secara offline, metode pemasaran dapat juga

dilakukan secara online menggunakan media sosial maupun e-commerce. Media sosial saat ini keberadaannya sangat berkembang pesat sehingga sangat prospektif dijadikan sebagai media pemasaran. Media sosial yang digunakan untuk pemasaran produk ini yaitu whatsapp, facebook dan instagram. Sementara itu, untuk e-coomerce yang digunakan yaitu Shopee dan Tokopedia. Kegiatan pendampingan dan pelatihan pembuatan telur asin asap pedas tersaji pada Gambar 3 dan produk telur asin asap pedas yang siap dipasarkan disajikan pada Gambar 4.

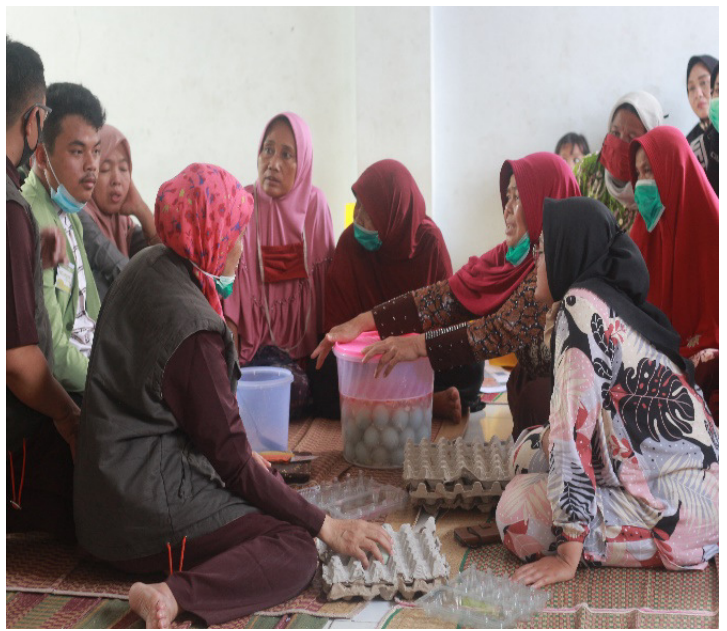

Gambar 3. Kegiatan pendampingan dan pelatihan pembuatan telur asin asap pedas

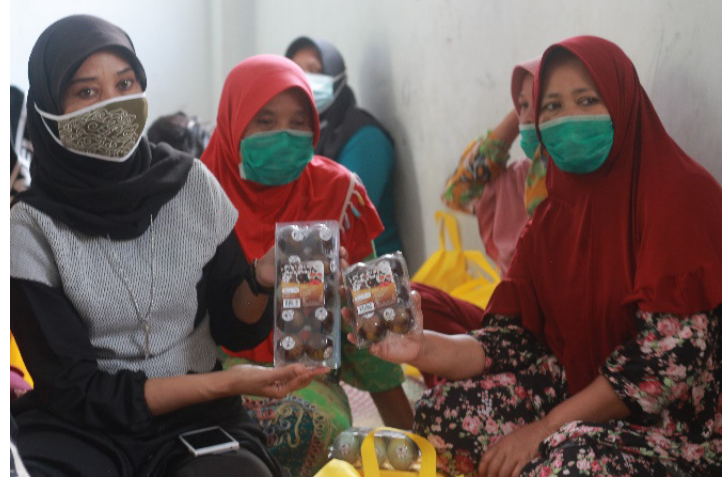

Gambar 4. Produk telur asin asap pedas yang siap dipasarkan
Hasil pendampingan dan monitoring tim pengabdian masyarakat pada kegiatan pengolahan telur asin asap rasa pedas ini menunjukkan para peserta sangat antusiasi untuk mempraktekkan ulang pembuatan telur asin asap rasa pedas ini di rumahnya masingmasing. Selain itu, beberapa peserta melakukan konfirmasi ingin membuka usaha pembuatan telur asin asap pedas ini. Para peserta menyadari bahwa pengolahan telur itik segar menjadi telur asin asap pedas memiliki citarasa yang enak dan lebih disukai dibandingkan telur asin biasa. Peserta juga menyadari bahwa keuntungan yang didapatkan dengan cara mengolah telur itik menjadi telur asin asap pedas ini akan jauh lebih besar. Peserta kegiatan pengolahan telur asin asap pedas disajikan pada Gambar 5.

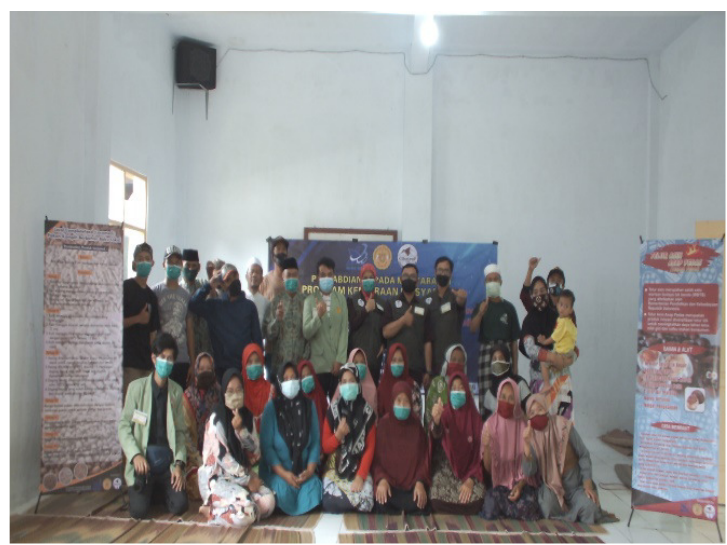

Gambar 5. Peserta kegiatan pengolahan telur asin asap pedas

\section{KESIMPULAN}

Peserta kegiatan telah mendapatkan transfer ilmu pengetahuan berupa teknik pengolahan telur itik segar menjadi telur asin asap pedas, pengemasan produk sampai strategi pemasaran produk menggunakan berbagai media sosial dan e-commerce. 
Para peserta sangat antusias dan berpartisipasi aktif di dalam kegiatan tersebut. Pengetahuan dan keterampilan yang sudah diterima peserta diharapkan dapat terus diaplikasi di dalam kehidupan sehari-hari baik sebagai pangan harian maupun alternatif bisnis yang akan dijalankan.

\section{UCAPAN TERIMAKASIH}

Terimakasih disampaikan kepada

Direktorat Riset dan Pengabdian Masyarakat

Kemendikbudristek yang telah mendukung pendanaan melalui kegiatan Program Kemitraan Masyarakat.

\section{REFERENSI}

[1] Lukito, G.A., Suwarastuti, A., Hintono, A. 2008. Pengaruh Berbagai Metode Pengasinan Terhadap Kadar $\mathrm{NaCl}$, Kekenyalan dan Tingkat Kesukaan Konsumen pada Telur Puyuh Asin. Jurnal Animal Agriculture. 1(1): 829 838.

[2] Nuruzzakiah, Rahmatan, H., Syafrianti, D. 2016. Pengaruh Konsentrasi Garam Terhadap Kadar Protein Dan Kualitas Organoleptik Telur Bebek. Jurnal Ilmiah Mahasiswa Pendidikan Biologi. 1(1): 1 -9 .
[3] Novia, D., Juliyarsi, I., Fuadi, G. 2012. Kadar Protein, Kadar Lemak dan Organoleptik Telur Asin Asap Berbahan Bakar Sabut Kelapa. Jurnal Peternakan. 9(1): $35-45$.

[4] Fajriana, E., Jaelani, A., Gunawan, A. 2020. Pengaruh Media Pengasapan terhadap Kualitas Eksterior dan Organoleptik Telur Asin Asap. Rawa Sains: Jurnal Sains STIPER Amuntai. 10(1): 26-37.

[5] Simanjuntak, O. E., Wasito, S., Widayaka, K. 2013. Pengaruh Lama Pengasapan Telur Asin dengan Menggunakan Serabut Kelapa terhadap Kadar Air dan Jumlah Bakteri Telur Asin Asap. Jurnal Ilmiah Peternakan. 1(1): 195 - 200.

[6] Jaelani, A., Zakir, M.I. 2018. Kualitas Organoleptik Telur Asin Asap dengan Lama Pengasapan Berbeda. Prosiding Hasil-Hasil Penelitian Dosen-Dosen Uniska MAB. Uniska MAB. Banjarmasin.

[7] Reringga, L., Mursalin, Rahmayani, I. 2019. Kajian Proses Pengeringan Cabai Merah (Capsicum annum L.) Menggunakan Vaccum Dryer dengan Penambahan Maltodekstrin dan Aplikasinya dalam Pembuatan Abon Cabai. Semirata BKS PTN Wilayah Barat 27 - 29 Agustus 2019. Hal. 1395 1414 